\title{
Monika Krawiel
}

Wydział Filologiczny

Uniwersytet w Białymstoku

e-mail: monika.krawiel@o2.pl

\section{Michał Głowiński: literaturoznawca i pisarz Zagłady}

Michał Głowiński przez wiele lat uważany był przede wszystkim za wybitnego naukowca, zajmującego się teorią literatury. Stał się wzorem dla innych przedstawicieli tej dyscypliny. W ostatnich latach postrzegany jest jednak przede wszystkim jako wybitny pisarz Zagłady. Można zatem postawić pytanie, czy bycie literaturoznawcą wpłynęło na twórczość beletrystyczną pisarza? Sądzę, że tak i to w sposób znaczący. Głowiński przez wiele lat zajmował się analizą dzieł innych autorów, także tych, którzy tworzyli krótkie formy narracyjne (chodzi m.in. o małe prozy Mirona Białoszewskiego). Jako ich badacz zwracał uwagę na te kategorie, które okazały się priorytetowe w jego własnych utworach wspomnieniowych. Dlatego sądzę, iż kompetencje literaturoznawcze nie stanowiły żadnej przeszkody, ani nie stały się ograniczeniem dla twórczości literackiej Michała Głowińskiego, a wręcz przeciwnie - pomogły mu zmierzyć się z ważnym tematem, wobec którego wielu pisarzy okazało swą bezradność: z Zagładą.

Ukazawszy czytelnikom historię dziecka Zagłady, która jest głównym tematem małych próz Michała Głowińskiego, pisarz zdecydował się na przedstawienie swojej całościowej autobiografii w Kręgach obcości. Obok żydowskości i klaustrofobii, motywów znanych z jego wcześniejszych tekstów, pojawił się w niej inny krąg obcości - homoseksualizm, o którym pisarz dotychczas publicznie nie mówił ${ }^{1}$.

1 Warto przyjrzeć się tekstowi Aleksandry Ubertowskiej, w którym badaczka zwraca uwagę 


\section{Małe prozy Michała Głowińskiego}

Swoją twórczość beletrystyczną Michał Głowiński rozpoczął od krótkich opowiadań: Czarne sezony, Magdalenka z razowego chleba, Historia jednej topoli, Fabuly przerwane, Kładka nad czasem. Opowieści z miasteczka, Przewidzenia i figury. Długie formy narracyjne, zdaniem pisarza, „lepiej służą mówieniu o trwaniu niż o końcu ${ }^{2 \prime}$, czego świadomość zyskał przy niejednokrotnym analizowaniu i interpretacji powieści innych autorów. Bazując na poetyce fragmentu, Głowiński stara się w swojej prozie być wiernym własnej pamięci. Chce, aby karty jego dzieł nie były zapełnione zwykłą fabułą, nic niewnoszącą do życia, której zresztą, jak sam niejednokrotnie podkreśla, nie umiałby nawet napisać.

Swoje opowieści Głowiński początkowo pisał, jak sam określa, „do szuflady”, z tego też względu chciał być szczery przede wszystkim sam ze sobą. Zdaniem badacza kreowanie fikcji na bazie rzeczywistości śmierci i Zagłady jest niestosowne, bo zaciera ich prawdziwy obraz, dlatego w swoich narracjach każdorazowo powiadamia czytelnika o pojawieniu się elementów fikcjonalnych. Osoby, które tak nie postępują, dopuszczają się, według niego, nierzetelności. O utworach pisarza można powiedzieć, że są swoistym continuum wierności pamięci. Tam, gdzie pojawia się wątek Zagłady, autor odrzuca nieprawdę, zmyślenie.

O tożsamości małych próz Michała Głowińskiego decyduje ich fragmentaryczność, realizowana na obszarze języka, współdecydująca o czasie, przestrzeni, wykorzystanych kontekstach i konstrukcji postaci. Warto pokrótce przyjrzeć się wszystkim tym aspektom jego pisarstwa.

\section{Fragmentaryczność}

Michał Głowiński, będąc literaturoznawcą, doskonale zdawał sobie sprawę z niezwykłej roli opowiadania jako gatunku w literaturze odnoszącej się do „Epoki Pieców”, dlatego też upodobał je sobie szczególnie we

na skrzyżowanie się w biografii Głowińskiego dwóch płaszczyzn tożsamości: żydowskości $\mathrm{i}$ homoseksualizmu. To one $\mathrm{w}$ dużym stopniu wpłynęły na alienację pisarza. Ubertowska $\mathrm{w}$ tytule swego tekstu określiła to „podwójnym wyjściem”. Wskazała też na różnice i podobieństwa dostrzeżone pomiędzy opowieścią autobiograficzną Głowińskiego a powstałymi wcześniej opowiadaniami wspomnieniowymi. Zob. A. Ubertowska, "Kręgi obcośsi”, podwójne wyjście. Projekt autobiograficzny Michała Głowińskiego, „Teksty Drugie” 2011, nr 4, s. 195-205.

2 J. Kurkiewicz, Punkty pamięci, „Tygodnik Powszechny” 2003, nr 24, http://www2.tygodnik. com.pl/ksiazki/24/ksiazki03.php [dostęp 20.11.2016]. 
własnej twórczości. To opowiadanie i jego fragmentaryzm pozwoliły na ukazanie losów dziecka, któremu przyszło żyć podczas wojny. Pisarz w swoich tekstach zastosował narrację pierwszoosobową, co można również uznać za walor szczególny jego twórczości. Narracja jest prowadzona w sposób prosty, bez zbędnej ornamentyki. Jedynie Kładka nad czasem. Opowieści z Miasteczka to książka nieco inaczej skomponowana, uznana zresztą za najbardziej literacką. Można w niej dostrzec doskonałą orientację literaturoznawcy w technikach narracyjnych.

W utworach wspomnieniowych Michała Głowińskiego istotna jest fragmentaryczność narracji. Z niej wynika konstrukcja pozostałych kategorii opisujących małe prozy. Świat się rozpadł, doszło do Zagłady. Pozostały jedynie strzępki, skrawki, z których nie da się na nowo zbudować całości, co znajduje swoje odzwierciedlenie $\mathrm{w}$ formie prozy Głowińskiego. Pisarz sam zaznacza, iż najciekawsze relacje dotyczące literatury Zagłady to są rzeczy fragmentaryczne ${ }^{3}$. Poetyka fragmentu to atut jego twórczości, czynnik wyróżniający ją spośród innych opowiadań. Jego małe prozy skomponowane są w postaci zbiorów "klatek”, na kształt tych stosowanych niegdyś w filmach czy kliszach fotograficznych ${ }^{4}$. Narracja oparta została na migawkowych obrazach, powtarzających się fragmentach przeszłości. Pojedyncze, niekiedy wyizolowane wspomnienia Głowińskiego można nazwać cytatami, wyjętymi z całości obrazu przeżytej wojny. Cytatami, które pamięta i które z jakiegoś powodu okazują się dla niego ważne. Fragmentaryczność jest uwarunkowana z jednej strony rozpadem świata po Zagładzie i niepamięcią autora, który był wówczas dzieckiem, z drugiej zaś wynika ona z predylekcji pisarza do prozy wspomnieniowej uformowanej jako portret - parabola. Sam Głowiński Czarne sezony określił „błyskami pamięci”, które „mają swoje prawa, zwalniają z troski o konsekwencję, uzasadniają fragmentaryczność, wręcz z góry ją zakładają" 5 . Narracja zatem nie jest linearna i ciągła - to szereg opowieści powiązanych tematyką Zagłady.

3 M. Głowiński, Posłowie, w: I. Amiel, Osmaleni, Izabelin 1999, s. 103.

${ }^{4} \mathrm{~W}$ analizie tego typu opowieści przydatna może okazać się koncepcja Rogera Browna i Jamesa Kulika „pamięci - lampy błyskowej”. Zob. Flash-bulb memories, „Cognition” 1977, nr 5, s. 73-99. Tekst dostępny także na stronie: http://arts.uwaterloo.ca/ dsmilek/psych398/Flash bulb\%20Memories.pdf [dostęp 12.11.2016].

5 M. Głowiński, Czarne sezony, Warszawa 1999, s. 7. Kolejne cytaty lokalizuję w tekście głównym. 


\section{Język}

Pisarz w swoich małych prozach starał się znaleźć taki sposób przedstawienia zdarzeń, który stałby się najodpowiedniejszy dla poruszanej tematyki. $\mathrm{W}$ jego opowiadaniach można dostrzec stopniowe przechodzenie od "przeżywanego do pojmowanego". Wśród wykorzystywanych przez niego często środków językowych można wyróżnić przede wszystkim pytania retoryczne, wykrzyknienia, wielokrotne powtórzenia, wartościującą frazeologię, porównania i metafory, które pozwalają autorowi wprowadzić czytelnika chociaż w minimalnym stopniu do świata Zagłady. W nazwaniu tego, co wydaje się nie do określenia, pomaga Głowińskiemu zwłaszcza metafora. Stała się ona nieoceniona $\mathrm{w}$ momentach, gdy groza i bestialstwo przedstawianych faktów sprawiały trudności w zapisie relacji o nich. Za sprawą wykorzystanych tropów i metafor, retorycznych struktur narracyjnych autor Czarnych sezonów starał się jak najwierniej ukazać obrazy będące $\mathrm{w}$ jego pamięci, podejmując próbę językowego wyrażenia codzienności Zagłady.

Dobrze znana Głowińskiemu jest też kategoria fait divers, którą można odnaleźć chociażby w Magdalence z razowego chleba czy też w Czarnych sezonach. Wymarzone ciastko, wyrwane z ręki ośmioletniego Michała na ulicy w getcie warszawskim przez inne wynędzniałe dziecko żydowskie staje się uogólniającym znakiem głodu, a zarazem aluzją do magdalenki Prousta. W małych prozach Głowińskiego można również pokusić się o wydobycie słów kluczy, wokół których toczy się cała narracja. Są to chociażby takie wyrazy, jak: getto, mur, obcość, samotność, dobry, zły wygląd, aryjska strona. One dookreślają utwory wspomnieniowe pisarza, stając się wątkami, wokół których toczy się narracja.

\section{Konteksty}

Głowiński w swoich zbiorach wspomnień podkreślał sensy ogólne, również te niosące ze sobą jakąś symbolikę. Jego narracje bogate są w aluzje literackie (np. aluzja do wspomnianej wcześniej magdalenki Prousta). W utworze pojawiają się cytaty i parafrazy, zaczerpnięte zarówno z utworów pisarzy polskiego pochodzenia, jak i tych zagranicznych.

Każdy z tytułów utworów należących do małej prozy Michała Głowińskiego odsyła czytelnika do literatury; przykładowo Kładka nad czasem. Obrazki z Miasteczka nawiązuje do Miasteczka nad Utratą, o którym pisał także Jarosław Iwaszkiewicz w Młynach nad Utrata. W utworze Głowińskiego uważny czytelnik może doszukać się mnóstwa odniesień literackich, np. cy- 
tatów z Głuchoniemej Leśmiana czy też z Wesela Wyspiańskiego, o których autor sam wspomina $\mathrm{w}$ udzielanych wywiadach. Pisarz dodaje, iż można odnaleźć również odwołania do Stendhala (Czerwone i czarne), Dantego (Boska Komedia), twórców literatury rosyjskiej (Gogol), amerykańskiej (Faulkner) oraz utworów polskich romantyków (Ksiądz Marek, Lilla Weneda, Pan Tadeusz, Stepy Akermańskie). Pojawiają się cytaty i parafrazy z Trembeckiego czy też antyutopijnego Swifta ${ }^{6}$. Stwierdza też, iż były to zabiegi ściśle przez niego dopracowane i przemyślane oraz że zdaje sobie sprawę z trudności, jakie ich rozszyfrowanie może nastręczyć niektórym odbiorcom podczas lektury. Głowiński nazywa siebie w tym dziele „małym kronikarzem" 7 , który z wielką skrupulatnością opisuje miasteczko z jego wszelkimi walorami i mankamentami. Także Historia jednej topoli odsyła do różnorodnych tekstów kultury. Katarzyna Kuczyńska-Koschany ${ }^{8}$ wymienia chociażby aluzje do wierszy Tadeusza Różewicza (Drzezwo, Na ścięcie drzewa).

Warto przyjrzeć się również tytułowi Magdalenki z razowego chleba, który odnosi się do dwóch epizodów zawartych we wcześniejszych Czarnych sezonach, np. kromka chleba z masłem, którą otrzymał młody Głowiński od siostry Róży w Turkowicach [s. 143]. Drugi fragment dotyczy rzeczywistości getta i tego, jak chłopakowi na ulicy wygłodniałe dziecko wyrwało ciastko z ręki, zjadając je tak szybko, jakby je chciało pochłonąć z papierkiem [s. 27].

Jednym z ważnych kontekstów, stale pojawiających się $\mathrm{w}$ odniesieniu do twórczości Michała Głowińskiego, niesłychanie istotnym dla samego pisarza, jest muzyka. Odwoływał się do niej zarówno w utworach literaturoznawczych, jak i beletrystycznych. "Zacząłem słuchać muzyki namiętnie i to mi zostało do dziś. Czyli trwa już ponad sześćdziesiąt lat" 9 - stwierdza badacz. Słuchanie muzyki zawsze go odprężało i sprawiało mu radość, z czasem stając się ukojeniem dla obolałej duszy. Temu tematowi Głowiński poświęcił kilka szkiców, m.in.: Muzyka w powieści ${ }^{10}$ i Literackość muzyki-muzyczność literatury ${ }^{11}$. Niejednokrotnie $\mathrm{w}$ muzyce dostrzegał aspekty literackości (i odwrotnie).

\footnotetext{
6 P. Łuszczykiewicz, Przeżyć i pisać, „Nowe Książki” 2006, nr 6, s. 53.

7 M. Radziwon, Ostra rozprawa z nieznośnq pamięciq, "Gazeta Wyborcza” 2006, nr 32, s. 16.

8 K. Kuczyńska-Koschany, "Nosiłem w sobie strach i nie znałem języka, którym bym mógł mówić". O Czarnych sezonach Michała Głowińskiego, „Polonistyka” 2008, nr 9, s. 37.

9 "Autobiografia musi być kompromisem” - z Michałem Głowińskim rozmawia Jacek Leociak, „Kwartalnik Artystyczny" 2010, nr 2 (66), s. 40.

10 M. Głowiński, Muzyka w powieści, „Teksty” 1980, nr 2.

11 Tegoż, Literackość muzyki - muzyczność literatury, w: Pogranicza i korespondencje sztuk: studia, red. T. Cieślikowska, J. Sławiński, Wrocław 1980.
} 
Kładka nad czasem. Obrazki z Miasteczka to utwór, o którym Głowiński wspominał, iż jest nawiązaniem do pewnego dzieła muzycznego. Dzięki wywiadowi przeprowadzonemu z pisarzem przez Żanetę Nalewajk ${ }^{12}$ dowiadujemy się, iż inspiracją były dla niego Obrazki z wystawy Musorgskiego, które kompozytor napisał po śmierci swego przyjaciela. Głowiński stwierdza, że gdyby od lat najmłodszych nie słuchał muzyki, to nigdy by mu na myśl nie przyszły aluzje do utworów muzycznych. Oczywiście ich wychwycenie nastręczać może trudności czytelnikowi nieobeznanemu z muzyką klasyczną, dla pisarza wzajemne relacje utworu literackiego i muzycznego to temat niezwykle pasjonujący.

Kolejne małe prozy - Fabuły przerwane - nawiązują do Kładki nad czasem oraz do Przewidzeń i figur. Wszystkie trzy pozycje łączy przede wszystkim kwestia muzyki; stanowią one dowód świetnej orientacji autora $w$ tej dziedzinie $^{13}$.

\section{Postaci}

Głównym bohaterem opowiadań Głowińskiego jest sam ich autor - narrator, który, między innymi dzięki zastosowaniu narracji pierwszoosobowej, wzbudza sympatię czytelnika. W ostatnich latach dziecięcy narrator to figura dosyć często stosowana $\mathrm{w}$ prozie dokumentu osobistego ${ }^{14}$, przyciągająca uwagę i wywołująca empatię odbiorcy. W małych narracjach Michała Głowińskiego na pierwszy plan oprócz samej Zagłady wysuwa się postać bohatera, czyli małego-dorosłego, przedwcześnie dojrzałego chłopca, któremu Zagłada ukradła sielskie dzieciństwo. Młodemu Michałowi przyszło zmierzyć się z wyzwaniami i problemami dorosłych, mimo że, ze względu na swój wiek, był niedojrzały emocjonalnie. Głowiński, podobnie jak i inne dzieci, musiał szybciej dojrzeć. Bohater czuł się cały czas zaszczuty: „Nigdy nie zapomniałem, że jestem kimś w rodzaju zaszczutego zwierzęcia, które

\footnotetext{
12 Zob. Ż. Nalewajk, „Moja kładka wznoszona nad czasem różne ma wymiary...”, „Tekstualia” 2006, z. 7, s. 55-62.

13 Zob. M. Głowiński, Kręgi obcości. Opowieść autobiograficzna, Kraków 2010, s. 142-146.

14 Zob. szerzej: J. Kowalska-Leder, Doświadczenie Zagłady z perspektywy dziecka $w$ polskiej literaturze dokumentu osobistego, Wrocław 2009; dwie rozprawy obronione w Instytucie Badań Literackich: K. Sokołowska, Świat w oczach dziecka Holokaustu (Bogdan Wojdowski - Henryk Grynberg) oraz O. Orzeł-Wargskog, Zgładzone dzieciństwo. Podmiot dziecięcy w polskiej literaturze Holokaustu. Dziecięcą optykę w opisywaniu Zagłady dostrzec można m.in. w: Chlebie rzuconym umarłym Bogdana Wojdowskiego, Zimie o poranku Janiny Bauman, Suchych łzach Nechamy Tec, Malowanym ptaku Jerzego Kosińskiego czy w Losie utraconym Imre Kertésza.
} 
każdy, jeśli tylko zechce, może zastrzelić, rozdeptać czy też unicestwić w jakikolwiek inny sposób [...]" [s. 113]. Wiedział, że z każdej strony może czyhać na niego śmierć, musiał dokładnie zastanawiać się nad wypowiadanymi słowami, aby nie zdradzać swojej żydowskiej tożsamości. Niekiedy inne dzieci były w stosunku do niego okrutne. W jednym z opowiadań ze zbioru Czarne sezony pisarz wspomina sytuację, kiedy był zastraszany przez chłopaka, który chciał się na nim zemścić, ponieważ uważał, że jest on winny śmierci Pana Jezusa, w myśl nauki, jaką otrzymał na religii prowadzonej przez księdza Franciszka Bujalskiego [s. 150-151]. Innym razem przytacza słowa jednego z braci Z., których także spotkał w Turkowicach: „Wiemy, że jesteś Żydem, jutro będą tu Niemcy, to im o tym powiemy, a oni zrobią z tobą porządek" [s. 113]. Głowiński nigdzie nie mógł czuć się bezpiecznie, dodatkowo był bardzo samotny.

Lata tuż po wojnie były dla pisarza również ciężkie. Nadal ukrywał swoje żydowskie pochodzenie. Jego strach był potęgowany przekonaniami ludzi pokroju wspomnianego wcześniej księdza Franciszka Bujalskiego: „Byłem wówczas, w pierwszych latach pookupacyjnych, kłębkiem nerwów, nie potrafiłem wyzwolić się od okropnych przeżyć i lęków, one wciąż we mnie żyły i określały mój stosunek do świata [...] [s. 146]".

W Czarnych sezonach autor stawia siebie w cieniu zdarzeń, które opisuje, ale mimo to każe patrzeć czytelnikowi na nie z własnej perspektywy, niekiedy wręcz usiłuje narzucić odbiorcy swoją optykę. Autor, czyli narrator, jest także bohaterem zdarzeń, o których mówi w tekście, i ma na ich temat określoną opinię.

Bohater małej prozy Głowińskiego jest szczególnie uwrażliwiony nie tylko na dźwięki dochodzące z otoczenia, ale i na kolory, które do dziś utkwiły mu w pamięci. Oko i ucho były niezwykle wyczulone na każdy sygnał z zewnątrz, który mógłby sugerować zagrożenie, bo np. „dźwięki wydawane przez silnik mogły być zwiastunem śmierci" [s. 69]. Cała rzeczywistość, w jakiej żył młody bohater, stanowiła dla niego śmiertelne niebezpieczeństwo, kryła szereg pułapek. Musiał nauczyć się z nimi żyć, starać się przechytrzyć los. Głowiński przywołuje wszystkie te dźwięki i barwy (opis koloru getta), korzystając z figuratywnych właściwości języka, które mają pomóc przybliżyć myśli i uczucia bohatera.

Czas Zagłady zmienił bohatera Magdalenki z razowego chleba. Został „osmalony" 15 już na zawsze. W młodym wieku zatracił swoją dziecięcą radość, nie potrafił wyrażać własnych uczuć, nawet wobec najbliższych osób, co ukazuje fragment spotkania z matką po długim rozstaniu. Młody Głowiń-

15 Sformułowanie zaczerpnięte ze zbioru Osmaleni autorstwa Irit Amiel. 
ski nie wiedział, jak ma się wówczas zachować, co powiedzieć: „byłem [...] niezdolny do cieszenia się, radość znajdowała się poza repertuarem moich zachowań" [s. 125] - stwierdza. Wspomina, iż pierwsze zdanie, które wypowiedział do ukochanej osoby po tak długiej rozłące dotyczyło wszy, którą zobaczył na jej berecie. Ta nieumiejętność okazywania, a nawet przeżywania emocji była oczywiście efektem doświadczenia Zagłady, którego skutki okazały się długofalowe i nieodwracalne: „Mimo że dopiero przekroczyłem dziesięć lat, miałem już swój bagaż doświadczeń, nosiłem na sobie ów okupacyjny garb, którego w żaden sposób zrzucić nie mogłem [...]" [s. 138] - pisał bohater Czarnych sezonów.

\section{Czas}

Michał Głowiński na kartach swoich krótkich opowiadań autobiograficznych wielokrotnie wspominał, iż nie panuje nad chronologią poniewierki po aryjskiej stronie. Upływ czasu w tamtym okresie stał się bardzo trudny do zrelacjonowania i zobrazowania, podobnie zresztą jak złożona jest kwestia czasu jako takiego zarówno w prozie Głowińskiego, jak i innych świadectwach Holocaustu. Czas Zagłady jest w nich czasem najtrwalszym, bo zostaje na zawsze w pamięci każdego "osmalonego". Nie można zapomnieć o wydarzeniach, które rozegrały się w „Epoce Pieców”. Mimo że niektóre zapamiętane sytuacje trwały krótko, to jednak dla tamtych ludzi jedna godzina stawała się wiecznością. Przykładem może być sytuacja przyjścia szmalcownika po okup, przedstawiona w Czarnych sezonach i w Kręgach obcości. Był to potworny moment dla Głowińskiego i jego rodziny. Nikt z nich nie wiedział, czy ciotce uda się zdobyć pieniądze, czy zdąży przyjść, zanim mężczyzna się rozmyśli i wyda ich Niemcom. Nawet bezdusznemu szantażyście czas się dłużył, dlatego postanowił zagrać $\mathrm{w}$ szachy ${ }^{16} \mathrm{z}$ młodym bohaterem. $\mathrm{W}$ tym przypadku to oczekiwanie nazwać można grą nie w szachy, ale o życie, a więc o najwyższą stawkę.

Traumatycznych sytuacji, w których czas odgrywał wielką rolę, Michał Głowiński w swoim życiu doświadczył wielu. W opowiadaniu pochodzącym z Czarnych sezonów pisarz wspomina o ukrywaniu się w jednej z piwnic, gdzie panował straszny ścisk, było ciemno, nikt nie mógł wydobyć z siebie żadnego dźwięku. W pewnym momencie cisza została przerwana, ponieważ małe, kilkumiesięczne dziecko zaczęło płakać. Jego matka próbowała je uciszyć, ale nic nie skutkowało, nawet podane tabletki uspokajające. Każdy bał się

16 Grę w szachy ze śmiercią można było ujrzeć w filmie Ingmara Bergmana. 
o swoje własne życie, dlatego zaczęto myśleć nawet o uduszeniu dziecka, aby dać szansę na przetrwanie pozostałym. Oczekiwanie na najstraszniejsze stało się wiecznością. O czasie Zagłady nie można zapomnieć, ani się go pozbyć. Jest on nieśmiertelny.

Niekiedy czas dłużył się młodemu Głowińskiemu. Bywały dni, gdy w getcie kilkuletni chłopak pogrążał się w bezczynności. Nie było mu dane spędzić dzieciństwa wśród zabaw i uciech, właściwych jego wiekowi. Nie miał praktycznie żadnych własnych rzeczy, a czasu pod dostatkiem, dlatego sięgnął po literaturę, zaczynając od książeczki do nabożeństwa. Utkwiła mu w pamięci także Lokomotywa Tuwima, bajka Czukowskiego oraz przeznaczone dla dzieci wersje Robinsona Crusoe i Przygody Guliwera [s. 157]. Duże znaczenie miała dla niego również księga do nauki gry w szachy i wielki atlas niemiecki.

Dzieciństwo, które przypadło na czas Zagłady, okazało się momentem granicznym dla każdego Żyda. Po tym wydarzeniu nikt już nie był tą samą osobą, tracąc niewinność, stając się "dzieckiem z garbem potwornego doświadczenia, nawet gdy chciało się cieszyć życiem"17. Czas Zagłady, który jest obecny w małych prozach Głowińskiego, "się spełnił, ale przecież wciąż istniał w każdym, kto ocalał. Istniał tym bardziej, że dopiero po jego zakończeniu można było dokonać bilansu strat, a więc milczącego apelu zamordowanych" [s. 174]. „Czas odbiera nadzieję, ale ran nie goi” [s. 143] - pisał w Czarnych sezonach. Kategoria czasu jest wyjątkowa z tego względu, że to ona skazuje swoje ofiary na obcość - inność - wykluczenie, co szczególnie uwidacznia się w krótkich opowiadaniach poświęconych Zagładzie. Każda osoba, o której mówi Głowiński w swoich tekstach wspomnieniowych, jest z góry skazana na obcość. Czas, w którym przyszło jej żyć, naznaczył jej dalsze losy. Nikt nie uciekł przed Zagładą.

Kategoria czasu powraca wielokrotnie $\mathrm{w}$ utworach wspomnieniowych wielkiego literaturoznawcy. Warto zwrócić uwagę chociażby na tytuły małych narracji, które w sposób bezpośredni bądź aluzyjny nawiązują do upływającego czasu. W Fabułach przerwanych motyw ten uwidoczniony jest już na okładce książki, która przedstawia obraz trzech zegarów pozbawionych wskazówek. Niekiedy można odnieść wrażenie, iż kwestia upływającego czasu stała się obsesją Głowińskiego.

Obok czasu Zagłady, jednocześnie w jego ramach, funkcjonuje także czas biologiczny. „Był upał, świeciło słońce, pełnia sezonu wielkiego umierania przypadła na szczytowy punkt lata" [s. 19], pisał Głowiński w Czarnych sezonach. Dalej czytamy, że nawet pojawiające się wówczas słońce było „nieludz-

17 M. Głowiński, Realia, dyskursy, portrety: studia i szkice, Kraków 2011, s. 290. 
kie, okrutne i, jak wszystko za murami, przysparzało cierpień" [s. 19]. Także przyroda uczestniczyła w okrucieństwie tamtych wydarzeń.

\section{Przestrzeń ${ }^{18}$}

W swoich małych prozach Michał Głowiński wielokrotnie powracał do miejsc, w których przyszło mu żyć. Jednak w czasie Zagłady nie miał swego stałego miejsca pobytu. Ciągle musiał przemieszczać się, uciekać, szukać schronienia wśród ludzi dobrej woli. Niejednokrotnie jego przestrzeń tworzyło getto, którego obraz po wielu latach bardzo dobrze zapamiętał. Początkowo, jak stwierdza w opowiadaniu Ulamki z getta pochodzącym z Czarnych sezonów, nie wiedział, co oznacza słowo "getto", co to znaczy „zamkną nas w getcie, czy nie zamkną?" [s. 9]. Był dzieckiem, nigdy wcześniej nie słyszał wielu wyrażeń, z którymi zaczął się stykać. Tajemnicze słowo "getto" mały chłopiec wyobrażał sobie jako „ogromny wielopiętrowy powóz, jeżdżący po ulicach miasta, ciągnięty przez kilkanaście koni" [s. 9]. Szybko jednak jego wizje zostały brutalnie zrewidowane przez nadchodzące wydarzenia, a precyzyjnego znaczenia niezrozumiałego wówczas terminu nauczyły go bolesne doświadczenia.

Michał Głowiński już od samego początku powstania getta nie rozumiał tej „okolonej murami przestrzeni” [s. 10]. Getto było ogrodzone, a więc stanowiło rodzaj więzienia, gdzie panował chaos, obowiązywała godzina policyjna i przebywało tak dużo ludzi, że trzeba się było między nimi przeciskać. Pisarz bardzo dobrze zapamiętał kolory tej przestrzeni - szaro-brunatno-czarne barwy. Nie było w nich nic żywego, pogodnego, brak jakiegokolwiek urozmaicającego akcentu. „Kolor getta jest w moim wspomnieniu kolorem papieru, jakim przykrywano leżące na ulicy trupy, zanim je uprzątnięto" [s. 11], wspominał pisarz w Czarnych sezonach. Wszystko było wówczas poszarzałe, wyblakłe - "to właśnie ta barwa bez barwy - ani biała, ani popielata, ani nawet szara, określa kolorystykę getta, nadaje jej ton" [s. 11]. Tę barwę, będącą zarazem zaprzeczeniem koloru, Głowiński zapamiętał na zawsze i po wojnie dostrzegł jeszcze raz, w czarno-białym filmie Andrzeja Wajdy o Januszu Korczaku.

\footnotetext{
18 Kategorię czasu i przestrzeni można by było traktować łącznie jako czasoprzestrzeń, jednak uznałam za stosowne ich rozdzielenie. Czas to kategoria kluczowa z punktu widzenia prozy Michała Głowińskiego, w której powraca on do wojenno-okupacyjnej przeszłości naznaczonej Zagładą. Natomiast przestrzeń to obecnie kategoria o dużej metodologicznej suwerenności, zwłaszcza ze względu na perspektywę geopoetyki.
} 
Również ulice $\mathrm{w}$ getcie zapisały się $\mathrm{w}$ pamięci autora Fabuł przerwanych. Stawały się one dla pisarza: "labiryntową siecią, po jakiej błądził nie samotny wędrowiec, ale upokorzony, systematycznie pozbawiany wszelkich dóbr tłum, jeszcze nie całkiem świadomy, że zostanie mu odebrane dobro największe - życie" [s. 12]. Często na tych ulicach można było zobaczyć nędzę, głód i śmierć. Wszystko to budziło w nim lęk. Nigdy nie zdołał się z tym widokiem „oswoić", mimo że śmierć była wówczas na porządku dziennym i szybko zrozumiał jej reguły.

Przestrzeń w latach wojny oprócz getta, Umschlagplatzu, Treblinki tworzyły także punkty, w których młody Michał się ukrywał, m.in. piwnice. Miejsca te pisarz szczególnie zapamiętał, ponieważ przeżywał w nich strach i zmagał się z własnymi lękami związanymi z klaustrofobią, na którą choruje i z którą przez wiele lat bezskutecznie walczył. Piwnica to dla niego przestrzeń wypełniona głównie niepokojem. Ukrywało się $\mathrm{w}$ niej zawsze wiele osób. Wszędzie było ciemno, nikt nie miał prawa wydobyć z siebie żadnych oznak życia, ponieważ to mogłoby skazać innych na śmierć. $Z$ podobnym zamknięciem młody Głowiński zetknął się podczas transportu pociągiem z getta w Pruszkowie do getta warszawskiego. Tam również wszyscy byli zamknięci, ściśnięci. Podróż trwała dwie doby, mimo że odległość, jaka dzieliła oba getta, wynosiła zaledwie kilkanaście kilometrów [s. 16-17].

Pisząc o przestrzeni, która otaczała Głowińskiego, należy wspomnieć, iż zawsze były to miejsca małe, zamknięte, zakamuflowane. Młody chłopak wielokrotnie ukrywał się z matką u różnych ludzi. Wszystkie te miejsca tworzyły przestrzeń klaustrofobiczną, odseparowaną od reszty świata, a jednocześnie żadne $\mathrm{z}$ tych schronień nie było bezpieczne. Wszyscy, którzy się w nich ukrywali, mieli jednak nadzieję, że będzie to dla nich strefa ocalenia.

Literatura Zagłady zaczęła się dość prężnie rozwijać po 1989 roku, potwierdzając wyjątkowość tego wydarzenia oraz - paradoksalnie - swoją bezradność wobec niego, czego przejawem był rozpad tradycyjnych, epickich form narracji. $W$ tym paradygmacie mieści się też proza Michała Głowińskiego oraz jego decyzja, by sięgnąć po małe prozy i poetykę fragmentu. Pisarz nie przez przypadek wybrał ten typ wypowiedzi, który okazał się skuteczny także z punktu widzenia czytelników, zaś wpływ na tę decyzję z pewnością miało także jego doświadczenie. 
Trwałość swych literackich zatrudnień Michał Głowiński potwierdził wydając zbiór opowiadań zatytułowany Carska filiżanka ${ }^{19}$. Najnowsza książka wybitnego teoretyka stanowi uzupełnienie wcześniejszych rozważań podjętych najpierw $\mathrm{w}$ małych prozach, a następnie w opowieści autobiograficznej Kręgi obcości. Nowy zbiór opowiadań został napisany w tonie intymnego wyznania, niczym kartki z pamiętnika lub też miniatury przeszłości zanotowane w sposób chronologiczny (od dzieciństwa w sierocińcu po czas życia w PRL-u). Podobnie jak w poprzednich wspomnieniowych publikacjach autor odkrywa przed czytelnikiem swoją „inność", zachowując narrację pierwszoosobową i wyzbywając się fikcji literackiej. Tytułowa carska filiżanka staje się symbolem przeszłości, do której Głowiński ponownie powraca.

\section{Bibliografia}

Amiel Irit, Osmaleni, Izabelin: Wydawnictwo Świat Literacki, 1999.

"Autobiografia musi być kompromisem" - z Michałem Głowińskim rozmawia Jacek Leociak, „Kwartalnik Artystyczny” 2010, nr 2, s. 40.

Bauman Janina, Zima o poranku: opowieść dziewczynki z Warszawskiego getta, Kraków: Wydawnictwo Znak, 1989.

Brown Roger, Kulik James, Flash-bulb memories, „Cognition” 1977, nr 5, s. 73-99.

Głowiński Michał, Carska filiżanka: szesnaście opowieści, Warszawa: Wielka Litera, 2016. Głowiński Michał, Muzyka w powieści, „Teksty” 1980, nr 2.

Głowiński Michał, Literackość muzyki - muzyczność literatury, w: Pogranicza i korespondencje sztuk: studia, red. T. Cieślikowska, J. Sławiński, Wrocław: Zakład Narodowy im. Ossolińskich - Wydawnictwo PAN, 1980.

Głowiński Michał, Realia, dyskursy, portrety: studia i szkice, Kraków: Towarzystwo Autorów i Wydawców Prac Naukowych Universitas, 2011.

Kertész Imre, Los utracony, przeł. K. Pisarska, Warszawa: Wydawnictwo W.A.B., 2002.

Kosiński Jerzy, Malowany ptak, przeł. T. Mirkowicz, Warszawa: Wydawnictwo Czytelnik, 1989.

Kowalska-Leder Justyna, Doświadczenie Zagłady z perspektywy dziecka w polskiej literaturze dokumentu osobistego, Wrocław: Wydawnictwo Uniwersytetu Wrocławskiego, 2009.

Kuczyńska-Koschany Katarzyna, "Nositem w sobie strach i nie znałem języka, którym bym mógł mówić". O Czarnych sezonach Michała Głowińskiego, „Polonistyka” 2008, nr 9, s. 36-41.

Kurkiewicz Juliusz, Punkty pamięci, „Tygodnik Powszechny” 2003, nr 24, http:// www2.tygodnik.com.pl/ksiazki/24/ksiazki03.php [dostęp 20.11.2016].

Łuszczykiewicz Piotr, Przė̇yć i pisać, „Nowe Książki” 2006, nr 6, s. 53.

19 M. Głowiński, Carska filiżanka: szesnaście opowieści, Warszawa 2016. 
Nalewajk Żaneta, „Moja kładka wznoszona nad czasem różne ma wymiary...", „Tekstualia” 2006, z. 7, s. 55-62.

Radziwon Marek, Ostra rozprawa z nieznośna pamięcia, „Gazeta Wyborcza” 2006, nr 32, s. 16.

Tec Nechama, Suche łzy, przeł. K. Mantorska, M. Adamczyk-Garbowska, Warszawa: Wydawnictwo Baobab, 2005.

Ubertowska Aleksandra, "Kręgi obcości”, podwójne wyjście. Projekt autobiograficzny Michała Głowińskiego, „Teksty Drugie” 2011, nr 4, s. 195-205.

Wojdowski Bogdan, Chleb rzucony umarłym, Warszawa: Państwowy Instytut Wydawniczy, 1971.

\section{Michał Głowiński: \\ Literary Critic and Writer of Holocaust}

Summary

Michał Głowiński, who has been so far perceived primarily as a distinguished literary critic, well known for his analysis of the communist newspeak, is also the author of autobiographical narratives. The article analyzes certain aspects of Głowiński's writing, such as the characters, time, space, fragmentariness, contexts and language. After almost sixty years of silence, in his texts Głowiński uncovers the layers of memory which come from "the epoch of gas chambers". He does it in order to face the trauma of the Holocaust.

Keywords: Holocaust, literature, autobiographical narrative, Michał Głowiński 